\title{
THE SAFETY LEVEL OF CONCRETE PILE FOUNDATIONS UNDER INDUSTRIAL MONUMENTS
}

\author{
SANDER PASTERKAMP ${ }^{*}$ \\ ${ }^{1}$ Delft University of Technology \\ Faculty of Civil Engineering \\ Stevinweg 1, Delft, The Netherlands \\ e-mail: s.pasterkamp@tudelft.nl,web page: http://www.tudelft.nl (*corresponding author)
}

Keywords: Pile Foundation, Pile Capacity, Adaptive Reuse, Codes

\begin{abstract}
Prefabricated concrete piles have been used for the foundation of bigger buildings for about a century. Often a change in function, an addition (also vertically) or another type of alteration is required, resulting in different loads on the foundation. There are several complicating factors that return regularly in these assessments. The first one is a lack of data. Often drawings are missing or incomplete, e.g. showing only pile head dimensions or maximum calculated load but not the pile length, pile tip shape or material properties. Inspection is hard and only possible for the part directly under the pile head. And a third complication is that in The Netherlands there have only been official codes for piles since 1992.
\end{abstract}

Various calculation and design methods from WWII until 1985 are discussed to see if there is any consistency that might lead to an indication of the load bearing capacity of piles in The Netherlands from that era.

It is concluded that design rules for the load bearing capacity of concrete pile foundations in The Netherlands have been inconsistent over time. If the original detailed geotechnical calculations and/or structural drawings cannot be found in archives then the given ultimate loads cannot only not be exceeded; even if the load on a pile is currently less than stated on the technical specifications designers are advised not to increase the load.

\section{INTRODUCTION}

Prefabricated concrete piles have been used for the foundation of bigger buildings for about a century. Some of these buildings have now become industrial monuments, which has as a consequence that their life span will go beyond their original economic life span. This often requires a change in function, an addition (also vertically) or another type of alteration in order to maintain economic viability (use it or lose it), resulting in different loads on the foundation. The question is then whether or not the old piles can carry the new load with sufficient safety.

There are several complicating factors that return regularly in these assessments. The first one is a lack of data. Often drawings are missing or incomplete, e.g. showing only pile head dimensions or maximum calculated load but not the pile length, pile tip shape or material 
properties. Inspection is hard and only possible for the part directly under the pile head. And a third complication is that in The Netherlands there have only been official codes for piles since 1992. Before then pile foundations were designed using technical manuals with a much lower status.

Van Tol and De Jong ${ }^{1}$ discuss pile foundations under monuments. They treat mainly wooden pile foundations. According to them post-WWII pile foundations are in a much better shape because of the better quality of the soil research, the introduction of the cone penetration test (CPT), the introduction of concrete piles and the improving insight in the behaviour of pile foundations and the calculation methods derived from that. No further information is given.

Scholten and Vrouwenvelder ${ }^{2}$ discuss the backgrounds of the Dutch national standard series NEN 8700. This series is dealing with Assessment of existing structures in case of reconstruction and disapproval. It is currently under development and should finally contain eight parts as shown in Table 1.

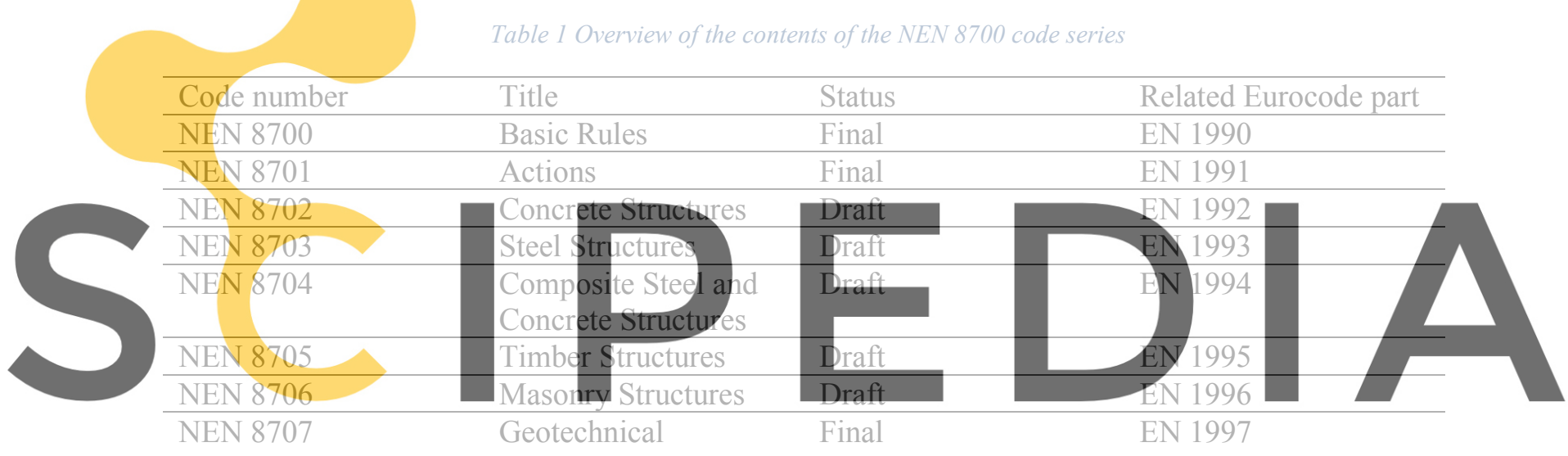

Register for free at https//ww Go.setipetidiz.com to download the version without the watermark

According to Scholten and Vrouwenvelder the safety assessment of an existing building structure differs from that of a new one in three essential ways: increasing the safety level for an existing building is usually more expensive than for buildings that are still in the design phase, the remaining lifetime of an existing building is often different from the standard reference period of 50 years that applies to new buildings, and in an existing building actual measurements can be made in order to gather additional data. This is reflected in the NEN 8700 series and is to some extent also true for pile foundations.

For existing concrete foundation piles the parts NEN8700, NEN 8701, NEN 8702 and NEN $8707^{3}$ are relevant. Together they give a set of values for required safety levels, loads, material properties, safety factors et cetera that can be entered into the common Eurocode formulas. The values follow from a set of research programs into the properties of construction materials as produced through old codes and production methods. Although this is very helpful for the assessment of existing structures in general it does not solve the basic problem of the unknown properties of the foundation under the specific building at hand. This is illustrated in NEN 8707:2018 in $\S 3.3$ : “(1) The quality of concrete foundation elements must be determined with 
sufficient accuracy to be able to verify it to the concrete related part of the NEN 8700 series."

F3O was the branch organization for independent foundation inspection experts. F3O has published a report titled "Guidelines Wooden Pile Foundations under Buildings"4. It gives alternative methods to assess the stability of pile foundations when the pile tip level is unknown, such as the measurement of deformations and cracks over time. From that it derives an expected remaining lifetime. This is an effective way to assess the stability of the current situation, however it does not give any information on possible overcapacity.

Rijkswaterstaat is part of the Dutch Ministry of Infrastructure and Water Management and responsible for the design, construction, management and maintenance of the main infrastructure facilities in the Netherlands. Rijkswaterstaat has published a report titled "Guidelines Assessment Infrastructure" or $\mathrm{RBK}^{5}$ for the structural assessment of existing structures. The RBK give rules and methods that are additional to the Dutch NEN 8700 code series. According to the RBK foundations only have to be recalculated in case of notable structural damage to the foundation, in case of serious settlements, or in case of a significant load increase. How foundation piles should be recalculated is not mentioned.

This study presents an investigation in de developments in designing, calculating and building prefab concrete pile foundations in the Netherlands during the last 80 years, and conclusions are drawn about load bearing capacity and the reusability of historic,
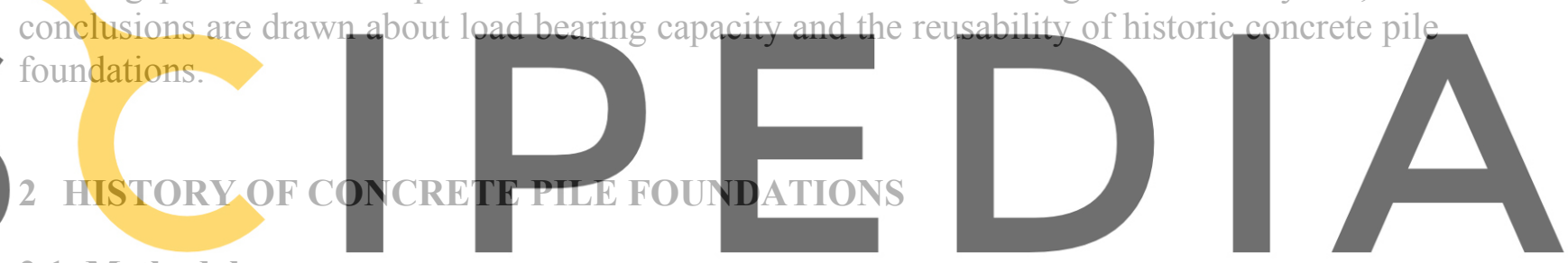

\subsection{Methodology}

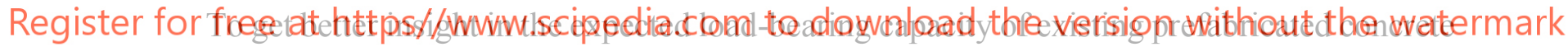
foundation piles we have to look in more detail at the way in which these piles were designed, produced, and placed. By comparing these aspects with the provisions of the Eurocode we can get an insight in possible over or undercapacity even if we have only limited information.

\subsection{Historic Pile systems}

Both according to Van Tol and De Jong ${ }^{1}$, and the author's own experience with many renovation projects pile foundations from before WWII are always wooden piles. The earliest use of concrete in pile foundations was first for foundation beams and then for pilecaps, to make sure the wooden pile head remains under the groundwater table. 


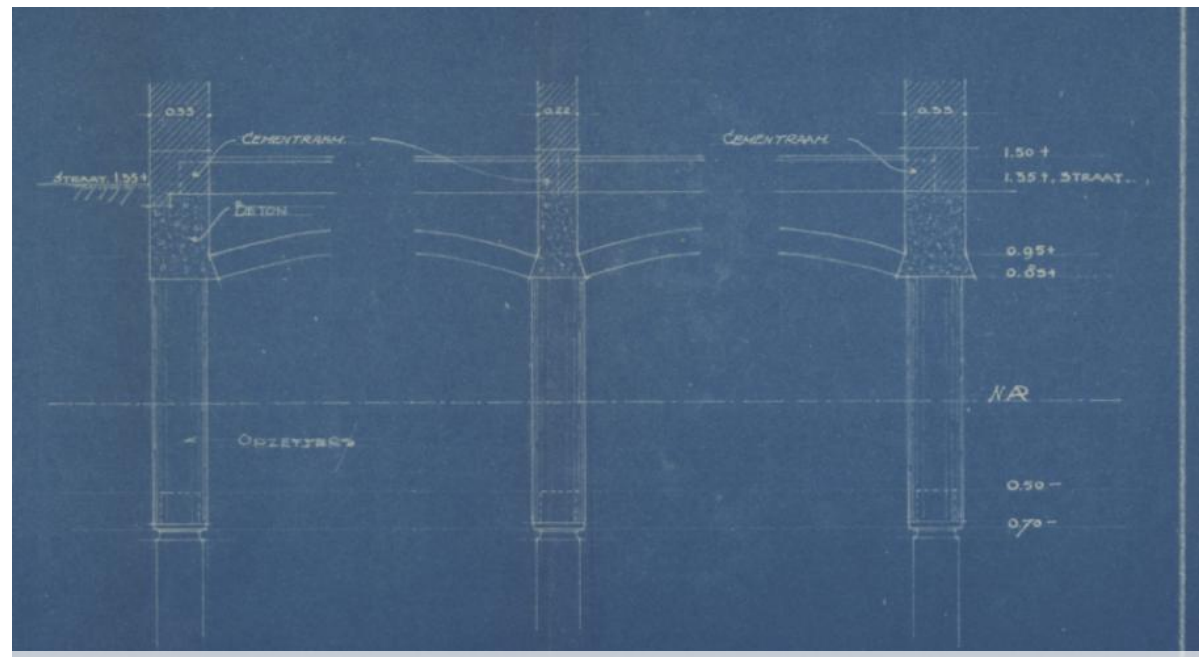

Figure 1 Concrete pilecap system "Brunwasser" on a construction drawing of a 1927 Amsterdam housing block

Van der Schrier describes in the 10th edition of his book ${ }^{6}$ the calculation and production of precast concrete foundation piles. The length of the piles is limited to $25 \mathrm{~m}$ for practical reasons. Reinforcement is traditional; only one factory (N.V. Betondak) is mentioned that produces pretensioned concrete piles. Van der Schrier nentions prismatic piles with square massive circular, and hollow circular sections always to be pointed or semi-pointed Van der Schrier also me tiphs var enlargements. According to Van der Schrier the pile capacity was supposed to be proportionate to the CPT value at the pile tip level and thus a bigger pile tip surface would directly result in a

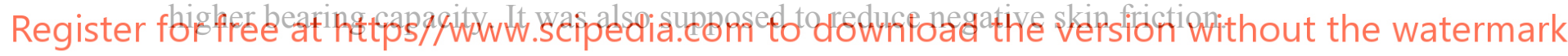
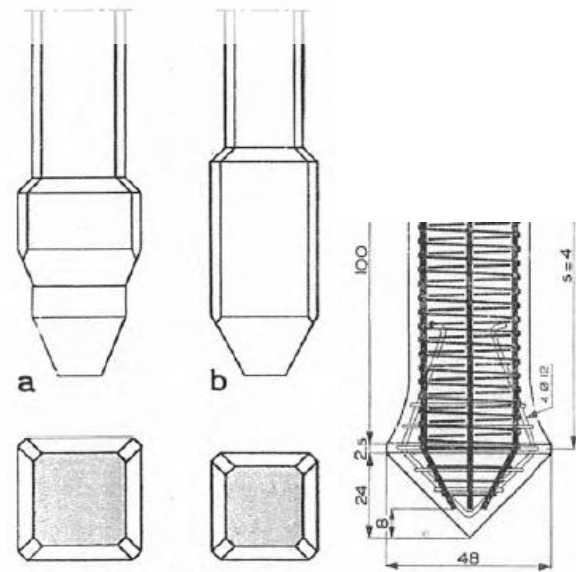

Figure 2 Pile tip shapes: a Waco point, b Sprenger point, c Condor point (Schrier, 1956)

One type of pile tip could be expanded through small explosive devices that would be set off 
just before the pile was driven to its final depth.

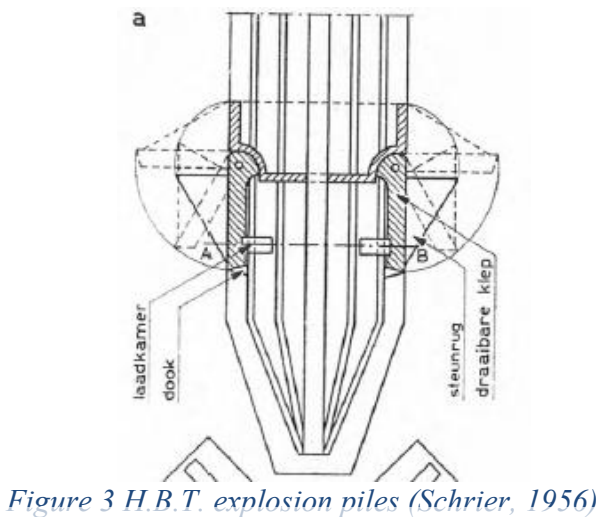

In spite of this the positive influence of shaft friction must have been known at least qualitatively. The wing pile was designed specifically to increase shaft friction and was therefore also recommended for piles loaded in tension.
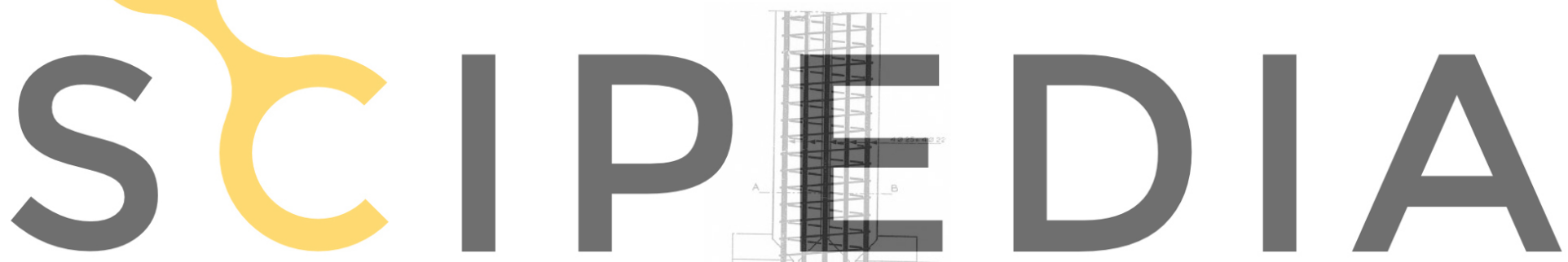

Register for free at https//www.scipedia.com to download the version without the watermark
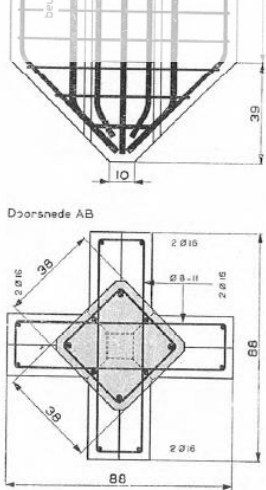

Figure 4 Pile tip of wing pile (Schrier, 1956)

17 years later Tussenbroek, Vlas, and $\mathrm{Krikke}^{7}$ mention in their book on prefabricated concrete piles much less variation in pile tip shapes. Only wide pile tips with a width-height ratio of at least 1 are mentioned and a ratio of at least 2 is recommended. Furthermore the pile tips are mostly flat (not pointed). He also has an entire chapter on prismatic prefabricated piles, 
indicating that this modern pile type is now very common.

\subsection{Bearing Capacity}

The bearing capacity of wooden piles before WWII was never calculated, but was assumed to be 10 tons or $100 \mathrm{kN}$ based on experience. The pile length was also based on local experience, usually meaning similar to that of neighbouring buildings. For bigger projects test piles were used. Van der Schrier (Schrier, 1956) mentions a table in the building regulations of the city of Amsterdam, stating the maximum displacement of the wooden pile head given 30 blows with a specified weight dropping $2 \mathrm{~m}$ if the pile has to take a certain load.

The current way in which pile bearing capacity is calculated in The Netherlands is originally based on research from Plantema ${ }^{8}$, and Van Mierlo and Koppejan ${ }^{9}$. It took some time for this research to seep through into building practice. Van der Schrier in 1956 still gives a simple calculation example of pile bearing capacity. The cone penetration test is basically seen here as a test pile. The influence of positive and negative skin friction is not mentioned.

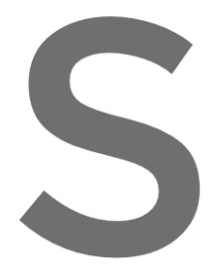

The size of the section of the pile tip enlargement follows from the result of a deep

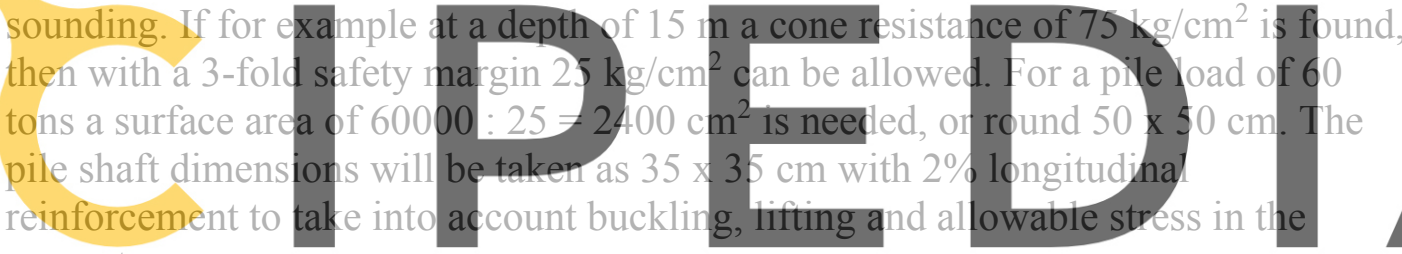
concrete.

Register for free at https//www.scipedia!coimatoridownhoadthe version without the watermark

Zeevaert ${ }^{10}$ still mentions that "theories on point bearing capacity of piles and piers are still not satisfactory". He then works out a method for the calculation of point bearing capacity of piles including positive skin friction based on Terzaghi's theories on the ultimate bearing capacity for a pier or deep footing. He also gives detailed theory for the calculation of negative skin friction.

Van Tussenbroek, Vlas, and Krikke ${ }^{7}$ mention the Koppejan method as a way to calculate the bearing capacity of piles, worked out in a way that quite closely resembles the current Dutch Eurocode practice. However according to them some organizations use different values for the influence depth of the ground layers above and below the pile tip level. The safety coefficient for a prismatic pile is 2.0 . For piles with a pile tip area of more than $100 \mathrm{~cm}^{2}$ a "somewhat bigger" coefficient is used. For piles with an enlarged pile tip "often a safety coefficient of 2.5 is used when the height of the enlargement is at least twice the pile tip width." For pile tips with a smaller height the safety coefficient becomes partially a correction coefficient and is enlarged by $10 \%$ for pile tip enlargements with a height equal to the width. 
According to Van Tussenbroek, Vlas, and Krikke the negative skin friction was usually just estimated but "recent measurements" have shown that the negative skin friction could become much greater than previously assumed. They refer to Zeevaert's book ${ }^{10}$ for further information.

In 1985 the Commission Consultation Building Structures of the Nuisance Act and Building Department Association (an organization of municipal building specialists) published the Guidelines for foundations of Buildings ${ }^{11}$. In the introduction they wrote that until then different cities had different regulations. The purpose of the new guidelines was to create more uniformity and thus to create more clarity for designers and builders. They are however still not an official standard and local governments still had the freedom to make up their own rules.

\subsection{Durability}

Reinforced concrete always carries the risk of corrosion of the reinforcement. One possible problem is carbonatation, although the carbonatation rate of underground concrete is relatively low. Another possible attack comes from peat acids. Van der Schrier mentions that when peat acids are present the pile is covered with a bitumen emulsion.

The risk of corrosion is greatly reduced with increasing concrete cover. Therefore the

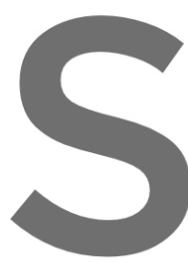
concrete cover in the
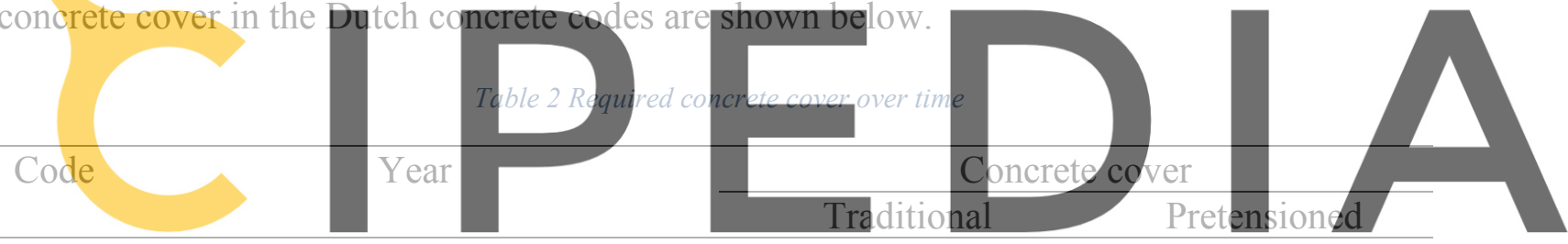

G.B.V. 1940

1940

$35 \mathrm{~mm}$

Register for free at https//wwW.SElpedia.com to downloadnthe version without the watermark N $1009 \quad 1962 \quad 30 \mathrm{~mm}$

\begin{tabular}{llll}
\hline RVB 1962 & 1962 & & $40 \mathrm{~mm}$ \\
\hline NEN 3863 & 1974 & $30 \mathrm{~mm}$ & $35 \mathrm{~mm}$ \\
\hline NEN 6720 & 1992 & $35 \mathrm{~mm}$ & $40 \mathrm{~mm}$ \\
\hline NEN-EN 1992 & 2012 & $25 \mathrm{~mm}$ & $30 \mathrm{~mm}$ \\
\hline
\end{tabular}

In all the historic codes the required concrete cover has been more that currently required by the Eurocode.

\section{CONCLUSIONS}

Design rules for the load bearing capacity of concrete pile foundations in The Netherlands have been inconsistent between WWII and the creation of the R.F.G. 1985. The exact calculation methods did not only differ over time but also geographically per city. Therefore it has to be concluded that care has to be taken when interpreting ultimate loads on foundation 
piles on historic documents. If the original detailed calculations cannot be found in archives then the given ultimate loads cannot only not be exceeded; even if the load on a pile is currently less than stated on the technical specifications designers are advised not to increase the load by for instance adding additional floors. For buildings for which the building permit was given in or after 1985 is can be assumed that the R.F.G. 1985 has been applied if the local government does not indicate otherwise. Designers are advised to ask.

In all the historic codes the required concrete cover has been more that currently required by the Eurocode. Durability of the concrete structure will therefore probably not be governing.

\section{LITERATURE}

[1] Veen, J.v.d. and S. Binst, Praktijkboek instandhouding monumenten. 1998, Den Haag: Sdu Uitgevers.

[2] Scholten, N.P.M. and A.C.W.M. Vrouwenvelder, Eurocodes and the structural safety of existing buildings - Considering the publication of the Dutch NEN 8700, in 4th International Conference CIVIL ENGINEERING`13. 2013: Jelgava.

[3] NEN, NEN 8707 Assessment of an existing structure in case of reconstruction and disapproval-Geotechnical constructions. 2018: Delft.

[4] F3O/SBRCURnet, Richtlijn Houten Paalfunderingen onder gebouwen. 2016.

[5] Rijkswaterstaat, Richtlijnen Beoordeling Kunstwerken. 2013, Rijkswaterstaat.

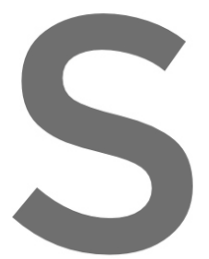

[6] Schrier, W.v.d., Bouwen in gewapexd beton : material,

toepassingen. $10 \mathrm{ed} .195$

[7] Tussenbroek, P.J.

Amsterdam [etc.]

[8] Plantema, G., Results of sounding, interpretation
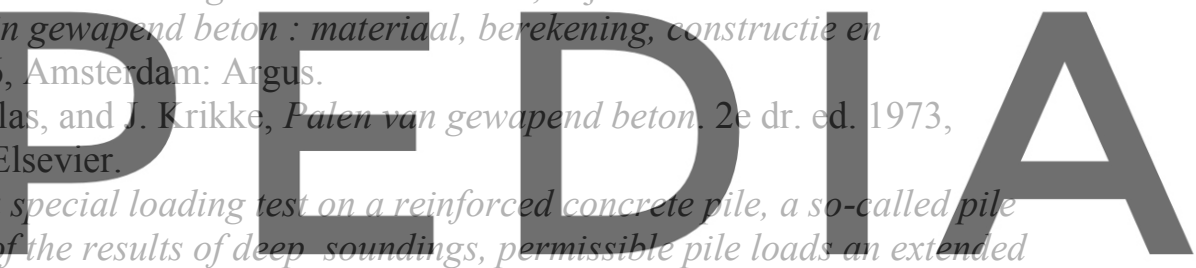

settlement observations, in Second International Conference on Soil Mechanics and

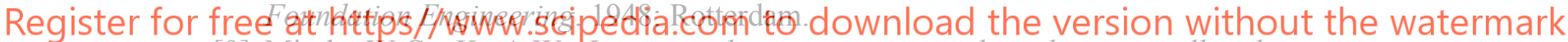

[9] Mierlo, W.C.v.K., A.W., Lengte en draagvermogen van heipalen; vaststelling hiervan en enige daarbij verkregen ervaringen. Bouw, 1952. 3

[10] Zeevaert, L., Foundation engineering for difficult subsoil conditions. 1973, New York: Van Nostrand Reinhold.

[11] bouwtoezichtvereniging, C.O.B.v.d.H.-e., Richtlijnen voor funderingen van gebouwen - R.F.G. 1985. 1988. 